\title{
Impact of aeration conditions on the removal of low concentrations of nitrogen in a tertiary partially aerated biological filter
}

\author{
Antonio Albuquerque ${ }^{\mathrm{a}, *}$, Jacek Makinia ${ }^{\mathrm{b}}$, Krishna Pagilla $^{\mathrm{c}}$ \\ ${ }^{a}$ Civil Engineering and Architectural Department, University of Beira Interior, Calçada Fonte do Lameiro, 6200-001 Covilhã, Portugal \\ b Faculty of Civil and Environmental Engineering, Gdansk University of Technology, Gabriela Narutowicza 11/12, 80-233 Gdańsk, Poland \\ ' Civil, Architectural and Environmental Engineering Department, Illinois Institute of Technology, 3201 South Dearborn Street, Room 228 Alumni Memorial Hall, Chicago, IL 60616- \\ 3793, USA
}

\section{A R T I C L E I N F O}

\section{Article history:}

Received 25 September 2011

Received in revised form 21 February 2012

Accepted 26 March 2012

\section{Keywords:}

Biological aerated filter

Denitrification

Nitrogen removal

Nitrification

Partial aeration

Residual removal

\begin{abstract}
A B S T R A C T
A submerged biological aerated filter (BAF) partially aerated was used to study the removal of low concentrations of ammonia nitrogen $\left(0.3 \mathrm{~g} \mathrm{~N} / \mathrm{m}^{3}\right.$ to $\left.30.5 \mathrm{~g} \mathrm{~N} / \mathrm{m}^{3}\right)$ typically found in nutrient enriched river and lake waters, and treated effluents. Four series of experiments were performed with a synthetic wastewater at ammonia loading rates between $6 \mathrm{~g} \mathrm{~N} / \mathrm{m}^{3} \mathrm{~d}$ and $903 \mathrm{~g} \mathrm{~N} / \mathrm{m}^{3} \mathrm{~d}$ and $\mathrm{C} / \mathrm{N}$ ratios from 2 to 20 . The results showed that ammonia removal rates reached higher values $\left(172 \mathrm{~g} \mathrm{~N} / \mathrm{m}^{3} \mathrm{~d}\right.$ to $564 \mathrm{~g} \mathrm{~N} / \mathrm{m}^{3} \mathrm{~d}$ ) for C/N $=2$ and lower values $\left(13.6 \mathrm{~g} \mathrm{~N} / \mathrm{m}^{3} \mathrm{~d}\right.$ to $34.6 \mathrm{~g} \mathrm{~N} / \mathrm{m}^{3} \mathrm{~d}$ ) for $\mathrm{C} / \mathrm{N}=20$. Between $50 \%$ and $70 \%$ of the ammonia was removed in the upper section of the BAF, where the dissolved oxygen (DO) concentration was over $2.1 \mathrm{~g}$ $\mathrm{O}_{2} / \mathrm{m}^{3}$ and the biofilm depth ranged from 0.4 to $0.6 \mathrm{~mm}$. At the bottom section of the reactor, simultaneous removal of ammonia and nitrate was observed at the DO concentrations in the range $0.4 \mathrm{~g} \mathrm{O}_{2} / \mathrm{m}^{3}$ to $0.8 \mathrm{~g} \mathrm{O}_{2} / \mathrm{m}^{3}$. There was no removal of ammonia nitrogen for loads below $15 \mathrm{~g} \mathrm{~N} / \mathrm{m}^{3}$. $\mathrm{d}$. The results indicate that the removal of nitrogen in partially aerated BAF may not only be explained by the conventional mechanisms of nitrification/denitrification.
\end{abstract}

(C) 2012 Elsevier B.V. All rights reserved.

\section{Introduction}

The discharge of nitrogen compounds to soil and waters may adversely affect water resources in several ways including contribution to eutrophication, depletion of oxygen, toxicity to aquatic environment and public health concerns. Nitrogen polluted surface waters including those from lakes and rivers often need to be pretreated prior to use in drinking water systems. Hence, removal of nitrogen (both reduced form such as ammonia and oxidized form such as nitrate) from treated waters and surface waters for reuse has become an important need to protect public health and reduce ecological risk. In order to satisfy stringent regulations concerning nitrogen removal from wastewater in the European Union (Urban Wastewater Directive 91/271/EEC, 10 to $15 \mathrm{~g} \mathrm{~N} / \mathrm{m}^{3}$ ) and USA (total $\mathrm{N}=3 \mathrm{~g} \mathrm{~N} / \mathrm{m}^{3}$ in some regions), conventional secondary wastewater treatment systems need to be retrofitted or the treatment scheme should be expanded with polishing treatment. The research described here addresses nitrogen removal from surface

\footnotetext{
* Corresponding author. Tel.: +351 275 242058; fax: +351 275329969.

E-mail addresses: ajca@ubi.pt, ajcalb@netvisao.pt (A. Albuquerque), jmakinia@pg.gda.pl (J. Makinia), pagilla@iit.edu (K. Pagilla).
}

waters and wastewater effluents using low maintenance and effective biological aerated filters.

Application of submerged biological filtration to remove residual loads (nutrients, trace elements and pathogens) as a tertiary and/or polishing step can be a promising alternative to retrofitting (Tchobanoglous et al., 2003; Jeong et al., 2006; Schulz and Menningmann, 2008; Farabegoli et al., 2009; Jenssen et al., 2010). Submerged biological aerated filters (BAF), also known as submerged aerobic biofilters (Schulz and Menningmann, 2008) present several advantages over other fixed-film reactors (e.g. rotating biological contactors (RBC) or trickling filters) including a high concentration of active biomass, good control of excess biomass, high sludge retention time (SRT) that enables degradation of complex compounds, better protection against toxic peaks by the biofilm, good efficiency of pollutant (carbon, nitrogen, phosphorous and pathogen) removal combined with a high filtering capacity in a single-unit process, easy maintenance and operation, no need for sludge recycling and a final clarifier (Mendoza-Espinosa and Stephenson, 1999; Grady et al., 1999; Tchobanoglous et al., 2003; Hidaka and Tsuno, 2004; Schulz and Menningmann, 2008). The capital cost of adding BAF as tertiary/polishing treatment is lower in comparison with construction of a new advanced treatment system and its construction does not interfere with the operation of existing reactors. 
The main disadvantages are the risk of clogging and energy costs associated with aeration and washing systems. Clogging may be minimized if solids could be properly removed upstream or by using media with void ratio over 0.4 (Grady et al., 1999; Farabegoli et al., 2009). The energy costs may be reduced by optimizing washing cycles and using low air flow rate or intermittent aeration. This last procedure may also be useful to change the biochemical environment in the filter from anaerobic to aerobic in order to promote simultaneously or alternately nitrification/denitrification mechanisms.

The media used in BAF must have suitable specific surface area $\left(500 \mathrm{~m}^{2} / \mathrm{m}^{3}\right.$ to $\left.2000 \mathrm{~m}^{2} / \mathrm{m}^{3}\right)$ to allow a good biofilm development, and a particle diameter ranging from 1 to $4 \mathrm{~mm}$ to allow a void ratio adequate for a good hydraulic flow rate (MendozaEspinosa and Stephenson, 1999; Albuquerque, 2003; Schulz and Menningmann, 2008). Mendoza-Espinosa and Stephenson (1999) point out removal efficiencies for organics and nitrogen over $80 \%$ in completely aerated BAF running with hydraulic loading rates (HLR) from $1 \mathrm{~m} / \mathrm{h}$ to $10 \mathrm{~m} / \mathrm{h}$. A natural porous volcanic rock (puzzolane) presents suitable properties for application in bioreactors and has been already tested in sequencing batch biofilter (Buitrón et al., 2004) for the removal of azo dye. Villaverde et al. (2000) have also tested this material in completely aerated BAF, but for the removal of high ammonia concentrations $\left(100 \mathrm{~g} \mathrm{~N} / \mathrm{m}^{3}\right)$. Operation air flow rates in BAF may range from $18 \mathrm{~L} / \mathrm{H}$ to $200 \mathrm{~L} / \mathrm{h}$ (He et al., 2007; Ha et al., 2010).

In a previous paper (Albuquerque et al., 2009a) the performance of a non-aerated lab-scale biofilter (filled with 2-4 mm of puzzolane particles) on the removal of organic matter (acetate), ammonia, nitrite and nitrate was analysed. In this study, the same reactor was converted to a partially aerated BAF and long-term operating data were analysed in terms of the removal of low ammonia nitrogen concentrations. Therefore, the aim of this study was to evaluate the effect of aeration on the performance of a puzzolanebased BAF reactor to remove low concentrations of ammonia nitrogen $\left(0.3 \mathrm{~g} \mathrm{~N} / \mathrm{m}^{3}\right.$ to $\left.30.5 \mathrm{~g} \mathrm{~N} / \mathrm{m}^{3}\right)$, which may constitute a useful mitigation measure for pollution control and integrated watershed management. Most of the previous works with BAF have used a total aerated filter to remove higher concentrations of ammonia (Mendoza-Espinosa and Stephenson, 1999; Villaverde et al., 2000; Stephenson et al., 2003; Garzon-Zuniga et al., 2005; Lei et al., 2009; Ha et al., 2010), normally from $25 \mathrm{~g} \mathrm{~N} / \mathrm{m}^{3}$ to approximately $650 \mathrm{~g} \mathrm{~N} / \mathrm{m}^{3}$ (i.e., the reactors were used mainly as a secondary treatment step). BAFs reactor studied in this paper could be used for restoration of ponds, lakes, and rivers polluted by cultural eutrophication as well as pollution prevention by treating wastewater effluents, which contain low nitrogen levels.

\section{Methodology}

\subsection{Experimental set-up}

A BAF reactor with $7.0 \mathrm{~cm} \times 40.5 \mathrm{~cm}$ (internal diameter $\times$ packing height) with a downward flow configuration was set-up for this study (Fig. 1). A homogeneous puzzolane material with an effective diameter of $4 \mathrm{~mm}$, specific surface area of $1740 \mathrm{~m}^{2} / \mathrm{m}^{3}$ and void ratio of 0.52 was used. The media bed was submerged $3 \mathrm{~cm}$ below the water level. Five sampling ports (P1-P5, $5 \mathrm{~mm}$ in diameter) were provided along the height of the reactor to collect water samples for analytical measurements. Another five ports in the same locations were connected to piezometers to evaluate variations in the hydrostatic pressure between the ports.

The reactor was also equipped with an external aeration device (TetraTec AP150 pump, Italy) with a flow rate control system and a maximum capacity of $150 \mathrm{~L} / \mathrm{h}$, connected close to the P2 sampling point (at approximately $8 \mathrm{~cm}$ from the media top). The air was injected into the reactor through a $4 \mathrm{~mm}$ tube with a fine bubble micro-diffuser. The aeration device introduced air upward in order to keep dissolved oxygen (DO) concentrations over $2 \mathrm{~g} \mathrm{O}_{2} / \mathrm{m}^{3}$ in the section MT-P2 (i.e., the reactor was partially aerated). This is one of the novelties of this work, since most of the previous works with BAF (Villaverde et al., 2000; Stephenson et al., 2003; Lei et al., 2009; Ha et al., 2010) used completely aerated filters with the aeration device located at the bottom of the reactors. A backwashing system was included in order to remove the excess of sludge produced during the BAF operation. The backwashing water flow rate was controlled by a rotameter (GARDENA T120, Italy), whilst the backwashing air flow rate was controlled by a pressure pump (VACUUBRAND ME 4R, Germany).

\subsection{Feeding solutions}

The feeding solution used for the experiments included a mineral medium (buffer, magnesium sulphate, calcium chloride and iron chloride solutions) and sources of organic carbon (sodium acetate) and ammonia (ammonia chloride), as previously described in Albuquerque et al. (2009a). The concentrated sodium acetate solution (113.4 $\mathrm{g} \mathrm{C}_{2} \mathrm{H}_{3} \mathrm{O}_{2} \mathrm{Na} \cdot 3 \mathrm{H}_{2} \mathrm{O}$ per $\mathrm{L}$ ) had a chemical oxygen demand (COD) concentration of $50 \mathrm{~kg} \mathrm{COD} / \mathrm{m}^{3}$ and a total organic carbon (TOC) concentration of $20 \mathrm{~kg} \mathrm{C} / \mathrm{m}^{3}$. The concentrated ammonia chloride solution $\left(76.41 \mathrm{~g} \mathrm{NH}_{4} \mathrm{Cl}\right.$ per $\mathrm{L}$ ) had a $\mathrm{NH}_{4}-\mathrm{N}$ concentration of $20 \mathrm{~kg} \mathrm{~N} / \mathrm{m}^{3}$.

During the normal operating conditions (excluding the experimental assays), the BAF reactor was fed with the synthetic wastewater with concentrations of COD of $100 \mathrm{~g} \mathrm{COD} / \mathrm{m}^{3}$ (equivalent to $40 \mathrm{~g} \mathrm{C} / \mathrm{m}^{3}$ ) and ammonia nitrogen $\left(\mathrm{NH}_{4}-\mathrm{N}\right)$ of $10 \mathrm{~g} \mathrm{~N} / \mathrm{m}^{3}$ (i.e., $\mathrm{C} / \mathrm{N}$ ratio of 4 ) as also used in Albuquerque et al. (2009a). The synthetic wastewater was prepared with tap water by diluting the concentrated solutions in the following proportions: $2 \mathrm{~mL} / \mathrm{L}$ of the buffer solution, $0.2 \mathrm{~mL} / \mathrm{L}$ of the magnesium sulphate solution, $0.2 \mathrm{~mL} / \mathrm{L}$ of the calcium chloride solution, $0.2 \mathrm{~mL} / \mathrm{L}$ of the iron chloride solution, $0.2 \mathrm{~mL} / \mathrm{L}$ of the oligoelements solution, $2 \mathrm{~mL} / \mathrm{L}$ of sodium acetate solution, and $0.5 \mathrm{~mL} / \mathrm{L}$ of ammonia chloride solution. For the experiments presented in the Table 1 the feeding solution composition was changed in order to obtain the influent $\mathrm{C} / \mathrm{N}$ ratios of $2,4,10$ and 20 . Therefore, the appropriate concentrations of COD (or TOC) and $\mathrm{NH}_{4}-\mathrm{N}$ were obtained by diluting the concentrated solutions of sodium acetate and ammonia chloride, according to the volumes presented in Albuquerque (2003). The feeding solution was kept in a storage tank (ISCO FTD 220, Italy) at a constant temperature of approximately $4{ }^{\circ} \mathrm{C}$ and pumped to the BAF reactor through a peristaltic pump (ISMATEC MCP CA4, Switzerland).

\subsection{Operation of the experimental $B A F$}

The operation of the BAF reactor involved two phases: investigating the backwashing cycle and achieving steady-state conditions with aeration (Phase I, 16 days), and performing experimental assays (Phase II, 102 days) for different ammonia nitrogen loading rates (NLR) and $\mathrm{C} / \mathrm{N}$ ratios. The reactor was previously operated without aeration during 152 days. Before the experiments, the reactor was inoculated with biomass from an activated sludge system treating municipal wastewater. The colonization took approximately 15 days in a closed circuit $(1 \mathrm{~L} / \mathrm{h})$ and discontinuous feeding. Approximately $38.9 \mathrm{~mL}$ and $9.7 \mathrm{~mL}$ of acetate and ammonia solutions, respectively, and a proportional volume of the mineral solutions were added to the reactor every $24 \mathrm{~h}$ in order to ensure the concentrations of $100 \mathrm{~g} \mathrm{COD} / \mathrm{m}^{3}$ and $10 \mathrm{~g} \mathrm{NH}_{4}-\mathrm{N} / \mathrm{m}^{3}(\mathrm{C} / \mathrm{N}=4)$ 


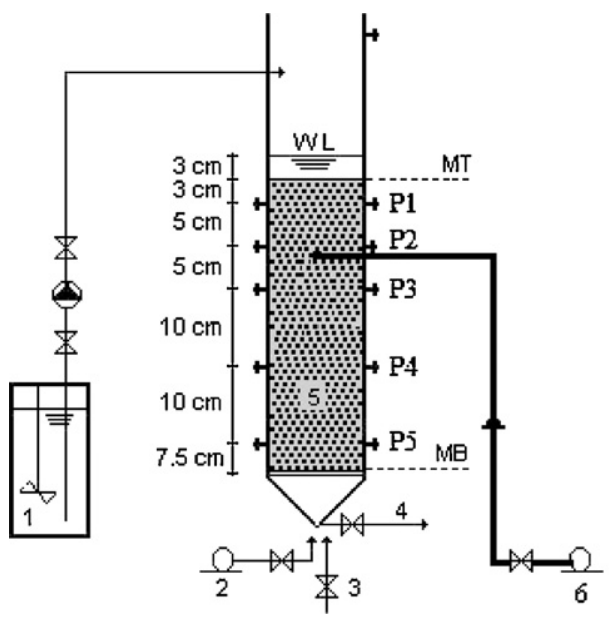

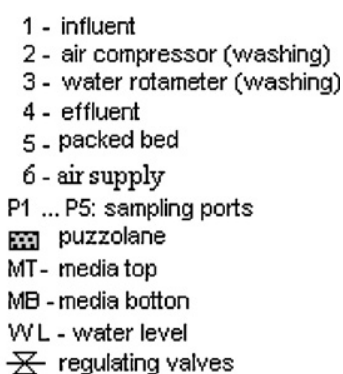

1 - influent

4 - effluent

5 - packed bed

6 - air supply

muzzolane

$\nabla$ regulating valves

Fig. 1. Schematic representation of the experimental BAF.

as described in Albuquerque et al. (2009a). In Phase II, four series of 24-h experiments with $\mathrm{C} / \mathrm{N}$ ratios of $2,4,10$ and 20 (20 assays) were performed as described in Table 1.

In Phase I, the backwashing cycle was defined under normal operating conditions (i.e., $100 \mathrm{~g} \mathrm{COD} / \mathrm{m}^{3}$ and $10 \mathrm{~g} \mathrm{NH} \mathrm{N}_{4}-\mathrm{N} / \mathrm{m}^{3}$ ), by operating the BAF until the steady-state conditions were broken. The backwashing period was selected in order to not allow the deterioration of the steady-state conditions. The head losses were determined daily in five reactor sections. During steady-state conditions, the measurements of $\mathrm{DO}, \mathrm{pH}$, temperature, TOC, COD and $\mathrm{NH}_{4}-\mathrm{N}$ were performed every 2 days in the influent, P2 and effluent. Backwashing was performed by injecting simultaneously upward air at the flow rate of $5 \mathrm{~L} / \mathrm{m}^{2} \mathrm{~s}$ $\left(\approx 68 \mathrm{~L} / \mathrm{h}, \approx 0.4 \mathrm{~m}^{3} \mathrm{air} / \mathrm{m}^{3}\right.$ media min) and water at the flow rate of $1 \mathrm{~L} / \mathrm{m}^{2} \cdot \sec \left(\approx 14 \mathrm{~L} / \mathrm{h}, \approx 0.3 \mathrm{~m}^{3}\right.$ water $/ \mathrm{m}^{3}$ media min $)$, during $10 \mathrm{~min}$. These conditions were set based on the recommendations of Mendoza-Espinosa and Stephenson (1999), i.e. air flow rates and water flow rates in the range of $0.4-0.5 \mathrm{~m}^{3} \mathrm{air} / \mathrm{m}^{3}$ media min and from 0.33 to $0.35 \mathrm{~m}^{3}$ air $/ \mathrm{m}^{3}$ media min, respectively, and are in the range of flow rates observed in the studies of Yang et al. (2010) and Liu et al. (2010), $5.3 \mathrm{~L} / \mathrm{m}^{2} \mathrm{~s}$ to $15 \mathrm{~L} / \mathrm{m}^{2} \mathrm{~s}$ (backwashing air flow rate) and $0.18 \mathrm{~L} / \mathrm{m}^{2} \mathrm{~s}$ to $5 \mathrm{~L} / \mathrm{m}^{2} \mathrm{~s}$ (backwashing water flow rate).
In the second phase, the reactor was operated continuously during 102 days to perform four series of experiments (altogether 20 assays) by modifying the organic loading and $\mathrm{C} / \mathrm{N}$ ratio in comparison with the steady-state conditions (Fig. 2). Between the experiments, for approximately 4 days (the period required to attain steady-state conditions, as shown in Albuquerque, 2003), the reactor feed was the same as that at steady state conditions (i.e., $100 \mathrm{~g} \mathrm{COD} / \mathrm{m}^{3}$ and $10 \mathrm{~g} \mathrm{NH}_{4}-\mathrm{N} / \mathrm{m}^{3}$ ). On the 5 th day, the operating conditions were modified for each individual experiment as presented in Table 1. In each assay, measurements of DO, $\mathrm{pH}$, temperature, TOC, $\mathrm{COD}, \mathrm{NH}_{4}-\mathrm{N}$, nitrite nitrogen $\left(\mathrm{NO}_{2}-\mathrm{N}\right)$, nitrate nitrogen $\left(\mathrm{NO}_{3}-\mathrm{N}\right)$, total suspended solids (TSS), volatile suspended solids (VSS) and alkalinity were performed at $12 \mathrm{~h}, 16 \mathrm{~h}$ and $20 \mathrm{~h}$ after changing the operating conditions (influent, the five sampling ports and effluent). In days $28,48,74$ and 108 , four grains of the media were collected in each of the five sampling ports in order to evaluate the biofilm thickness variations across the bed. TOC was occasionally determined to control the $\mathrm{C} / \mathrm{N}$ ratio, whereas COD analyses were used to follow the removal of acetate.

The aeration rate was kept at $20 \mathrm{~L} / \mathrm{h}$. The continuous or intermittent air flow rates between $3.5 \mathrm{~L} / \mathrm{h}$ and $18 \mathrm{~L} / \mathrm{h}$ are considered to be sufficient for the simultaneous removal of organic carbon and nitrogen according to Schulz and Menningmann (2008), Chang

Table 1

Influent characteristics for the experimental assays in Phase II.

\begin{tabular}{|c|c|c|c|c|c|c|c|c|c|}
\hline Days & Assay & $\mathrm{pH}$ & Temperature $\left({ }^{\circ} \mathrm{C}\right)$ & $\operatorname{COD}\left(\mathrm{g} \mathrm{COD} / \mathrm{m}^{3}\right)$ & $\operatorname{TOC}\left(\mathrm{g} \mathrm{C} / \mathrm{m}^{3}\right)$ & $\begin{array}{l}\text { Feed DO } \\
\left(\mathrm{g} \mathrm{O}_{2} / \mathrm{m}^{3}\right)\end{array}$ & $\mathrm{NH}_{4}-\mathrm{N}\left(\mathrm{g} \mathrm{N} / \mathrm{m}^{3}\right)$ & $\begin{array}{l}\text { Alkalinity } \\
\left(\mathrm{gCaCO}_{3} / \mathrm{m}^{3}\right)\end{array}$ & $\mathrm{C} / \mathrm{N}(\mathrm{g} \mathrm{C} / \mathrm{g} \mathrm{N})$ \\
\hline \multirow[t]{4}{*}{$18-42$} & A6.2.1. & 7.2 & 19.3 & 151.1 & 62.6 & 7.6 & 3.1 & 109.5 & 20.2 \\
\hline & A6.2.3. & 7.2 & 19.5 & 100.8 & 41.9 & 7.4 & 2.1 & 102.6 & 20.0 \\
\hline & A6.2.4. & 7.2 & 19.6 & 50.1 & 20.8 & 7.7 & 1.1 & 90.8 & 18.9 \\
\hline & A6.2.6. & 6.8 & 19.8 & 10.8 & 4.2 & 7.3 & 0.2 & 58.1 & 21.0 \\
\hline \multirow[t]{4}{*}{$44-62$} & A7.2.1. & 7.2 & 19.4 & 152.4 & 62.5 & 7.8 & 6.3 & 119.5 & 9.9 \\
\hline & A7.2.3. & 7.2 & 18.9 & 102.3 & 41.5 & 7.2 & 4.3 & 107.9 & 9.7 \\
\hline & A7.2.4. & 7.2 & 18.9 & 49.7 & 20.6 & 7.9 & 2.1 & 88.9 & 9.8 \\
\hline & A7.2.6. & 6.9 & 19.5 & 3.8 & 4.3 & 7.4 & 0.5 & 58.4 & 8.6 \\
\hline \multirow[t]{8}{*}{ 64-102 } & A8.2.1. & 7.2 & 19.5 & 155.3 & 62.5 & 7.4 & 15.8 & 126.7 & 4.0 \\
\hline & A8.2.2. & 7.2 & 19.6 & 131.5 & 52.2 & 7.9 & 12.6 & 117.9 & 4.1 \\
\hline & A8.2.3. & 7.2 & 20.4 & 101.8 & 41.8 & 7.3 & 10.2 & 115.8 & 4.1 \\
\hline & A8.2.4. & 7.2 & 18.8 & 52.3 & 20.6 & 7.7 & 5.1 & 95.4 & 4.0 \\
\hline & A8.2.5. & 7.1 & 19.2 & 25.8 & 10.2 & 7.0 & 2.5 & 70.2 & 4.1 \\
\hline & A8.2.6. & 7.1 & 18.9 & 11.2 & 4.4 & 7.3 & 1.1 & 55.4 & 4.0 \\
\hline & A8.2.7. & 6.9 & 19.5 & 5.2 & 2.1 & 7.2 & 0.5 & 39.6 & 4.2 \\
\hline & A8.2.8. & 6.8 & 19.7 & 3.1 & 1.0 & 7.5 & 0.3 & 22.5 & 3.3 \\
\hline \multirow[t]{4}{*}{$104-118$} & A9.2.1. & 7.2 & 19.2 & 150.8 & 62.4 & 7.6 & 30.5 & 123.8 & 2.0 \\
\hline & A9.2.3. & 7.3 & 19.5 & 102.6 & 41.6 & 7.7 & 20.4 & 123.8 & 2.0 \\
\hline & A9.2.4. & 7.2 & 19.5 & 52.3 & 20.8 & 7.8 & 10.2 & 85.4 & 2.0 \\
\hline & A9.2.6. & 7.1 & 19.1 & 9.8 & 4.2 & 7.6 & 2.1 & 52.2 & 2.0 \\
\hline
\end{tabular}




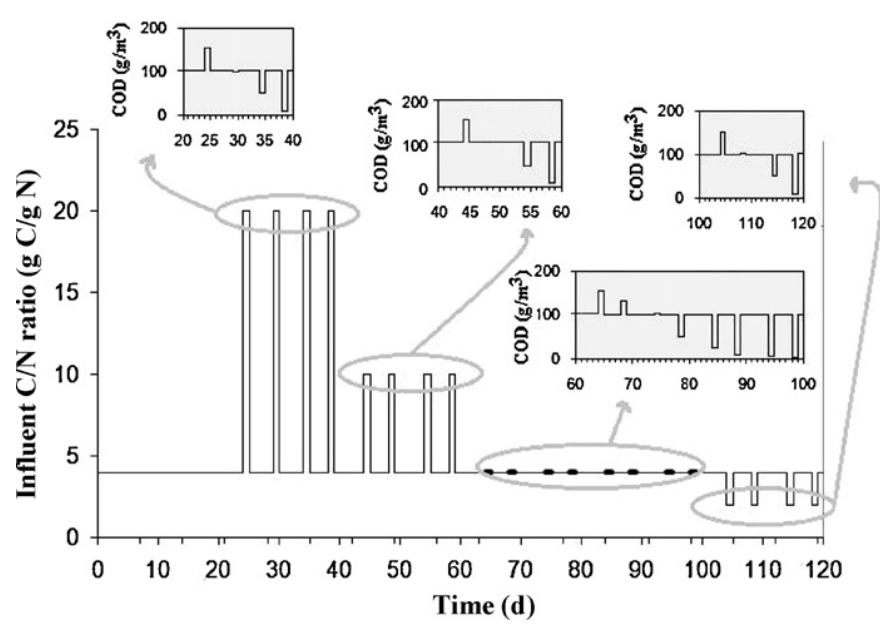

Fig. 2. Schematic representation of the operating conditions during Phase II.

et al. (2008) and Ha et al. (2010). For both phases, the reactor was operated at the flow rate of $1 \mathrm{~L} / \mathrm{h}$ (HLR of approximately $0.26 \mathrm{~m} / \mathrm{h}$ ). Recent studies showed good performance for ammonia removal at HLR up to $3 \mathrm{~m} / \mathrm{h}$ and air flow rate from $18 \mathrm{~L} / \mathrm{h}$ to $200 \mathrm{~L} / \mathrm{h}$ (Schulz and Menningmann, 2008; Lei et al., 2009; Ha et al., 2010; He et al.,
2007) in BAF completely aerated fed with higher ammonia concentrations ( $>100 \mathrm{~g} \mathrm{NH}_{4}-\mathrm{N} / \mathrm{m}^{3}$ ). The hydraulic retention time (HRT) was approximately $50 \mathrm{~min}$, which is in the range $(20 \mathrm{~min}$ to $2 \mathrm{~h}$ ) reported by Mendoza-Espinosa and Stephenson (1999) and Ha et al. (2010) for downflow BAF reactors. The hydrostatic pressure was recorded daily from each piezometer. The temperature in the BAF reactor was kept constant at approximately $20^{\circ} \mathrm{C}$ during the experimental phases.

\subsection{Analytical methods}

The DO, pH and temperature were measured with a D201 flow through vessel using probes SenTix 41 and CellOx 325 connected to the Multi 340i meter (WTW, Germany). Concentrations of organic carbon were measured as both COD, by closed reflux digestion and titrimetric method (APHA-AWWA-WEF, 1999), and TOC using the TOC-5000 analyzer (Shimadzu, Japan). Concentrations of $\mathrm{NH}_{4}-\mathrm{N}$ and $\mathrm{NO}_{2}-\mathrm{N}$ were measured through spectrophotometry according to the Standard Methods (APHA-AWWA-WEF, 1999), whereas $\mathrm{NO}_{3}-\mathrm{N}$ concentrations were measured using LCK 339 cuvette test $\left(0.23-13.5 \mathrm{~g} \mathrm{NO}_{3}-\mathrm{N} / \mathrm{m}^{3}\right)$ and the Cadas 50 spectrophotometer (HACH-LANGE, Germany). TSS and VSS concentrations were determined by the gravimetric method using $0.45 \mu \mathrm{m}$ pore size filters (APHA-AWWA-WEF, 1999). Alkalinity measurements
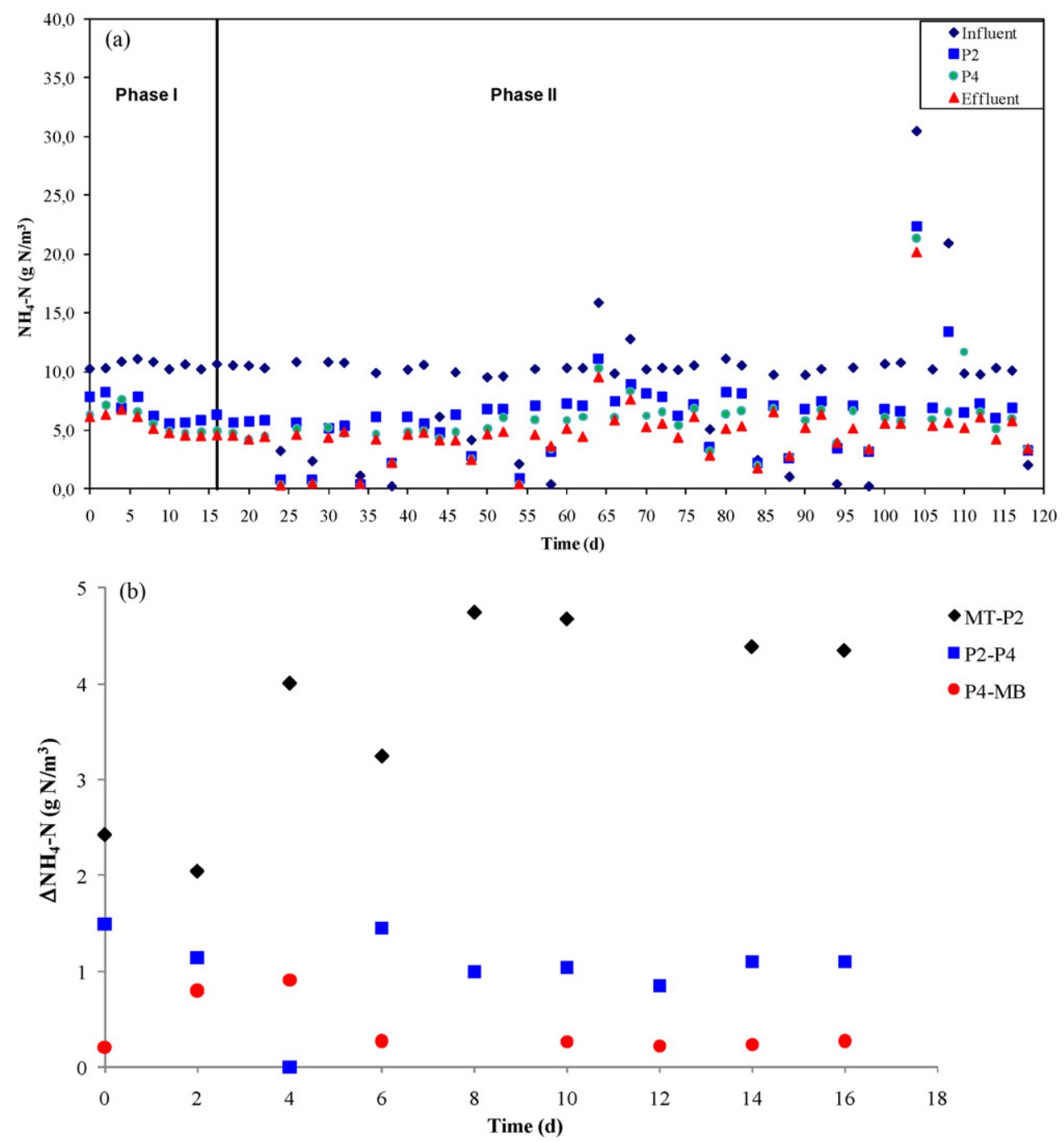

Fig. 3. Temporal variations of $\mathrm{NH}_{4}-\mathrm{N}$ concentrations at the influent, $\mathrm{P} 2, \mathrm{P} 4$ and effluent (a) and offloads of $\mathrm{NH}_{4}-\mathrm{N}$ removed during $\mathrm{Phase} \mathrm{I}$ (b). 
Table 2

Ammonia loading rates and ammonia removal rates in the experiments of Phase II.

\begin{tabular}{|c|c|c|c|c|c|c|}
\hline \multirow[t]{2}{*}{ Assays } & \multirow[t]{2}{*}{$\mathrm{C} / \mathrm{N}$} & \multirow[t]{2}{*}{$\mathrm{NLR}^{\mathrm{a}}\left(\mathrm{gN} / \mathrm{m}^{3} \mathrm{~d}\right)$} & \multicolumn{4}{|c|}{$r_{\mathrm{NH}_{4} \mathrm{~N}}\left(\mathrm{~g} \mathrm{~N} / \mathrm{m}^{3} \mathrm{~d}\right)$} \\
\hline & & & MT-P2 & $\mathrm{P} 2-\mathrm{P} 4$ & P4-MB & MT-MB ${ }^{\mathrm{a}}$ \\
\hline A6.2.1. & 20 & 91.8 & 94.4 & 26.4 & 14.4 & 34.6 \\
\hline A6.2.3. & & 62.2 & 69.0 & 30.4 & 0.0 & 27.8 \\
\hline A6.2.4. & & 32.6 & 52.5 & 9.6 & 0.0 & 13.6 \\
\hline A6.2.6. & & 5.9 & 0 & 0 & 0 & 0 \\
\hline A7.2.1. & 10 & 186.6 & 212.9 & 35.2 & 12.3 & 60.4 \\
\hline A7.2.3. & & 127.3 & 205.4 & 24.0 & 4.8 & 51.5 \\
\hline A7.2.4. & & 62.2 & 76.5 & 36.0 & 0.0 & 33.2 \\
\hline A7.2.6. & & 14.8 & 0 & 0 & 0 & 0 \\
\hline A8.2.1. & 4 & 467.9 & 860.5 & 103.9 & 66.5 & 237.2 \\
\hline A8.2.2. & & 373.1 & 586.1 & 43.2 & 50.0 & 153.4 \\
\hline A8.2.3. & & 302.0 & 577.2 & 72.8 & 20.6 & 149.8 \\
\hline A8.2.4. & & 151.0 & 226.4 & 28.8 & 27.4 & 67.2 \\
\hline A8.2.5. & & 74.0 & 45.0 & 12.8 & 19.2 & 21.9 \\
\hline A8.2.6. & & 32.6 & 0 & 0 & 0 & 0 \\
\hline A8.2.7. & & 14.8 & 0 & 0 & 0 & 0 \\
\hline A8.2.8. & & 8.9 & 0 & 0 & 0 & 0 \\
\hline A9.2.1. & 2 & 903.2 & 2149.7 & 310.2 & 56.2 & 563.8 \\
\hline A9.2.3. & & 604.1 & 1133.3 & 544.5 & 63.7 & 453.1 \\
\hline A9.2.4. & & 302.0 & 632.6 & 80.0 & 40.4 & 172.0 \\
\hline A9.2.6. & & 62.2 & 0 & 0 & 0 & 0 \\
\hline
\end{tabular}

a Calculated based on the total effective media volume (MT-MB): $0.00081 \mathrm{~m}^{3}$.

were performed by titration (APHA-AWWA-WEF, 1999). The biofilm thickness was evaluated using an electronic microscope (Hitachi S 2700, Japan) after dehydratation of the sample (substratum/biofilm) with acetone.

\section{Results and discussion}

\subsection{Phase I - steady state conditions}

The concentrations of ammonia observed in both phases are presented in Fig. 3(a). There was no detection of significant concentrations of nitrite $\left(0.1-0.2 \mathrm{~g} \mathrm{NO}_{2}-\mathrm{N} / \mathrm{m}^{3}\right)$ in all the sampling points for Phases I and II. Steady-state conditions were evaluated through the $\mathrm{NH}_{4}-\mathrm{N}$ load removal (Fig. 3(b)) that was attained in sections MT-P2, P2-P4 and P4-MB after approximately 8 days of the continuous operation. The BAF performance was analysed for sections MT-P2 (aerated section, aerobic), P2-P4 (section with residual oxygen, anoxic) and P4-MB (non-aerated section, anaerobic).

The average COD concentrations were $100.7 \pm 0.6 \mathrm{~g} / \mathrm{m}^{3}$, $60.6 \pm 7.1 \mathrm{~g} / \mathrm{m}^{3}, 38.4 \pm 2.2 \mathrm{~g} / \mathrm{m}^{3}$ and $28.8 \pm 1.3 \mathrm{~g} / \mathrm{m}^{3}$, respectively, in the influent, P2, P4 and effluent (considering 9 samples and a $95 \%$ confidence interval), which corresponds to average COD removal efficiencies (RE) of $40 \%, 35 \%$ and $25 \%$, respectively, for sections MT-P2, P2-P4 and P4-MB and an overall RE of $71 \%$. The average $\mathrm{NH}_{4}-\mathrm{N}$ concentrations at the same points were $10.6 \pm 0.2 \mathrm{~g} / \mathrm{m}^{3}, 6.7 \pm 0.7 \mathrm{~g} / \mathrm{m}^{3}, 5.8 \pm 0.7 \mathrm{~g} / \mathrm{m}^{3}$ and $5.4 \pm 0.6 \mathrm{~g} / \mathrm{m}^{3}$, which corresponds to average $\mathrm{RE}$ of $\mathrm{NH}_{4}-\mathrm{N}$ of $37 \%, 15 \%$ and $6 \%$, respectively, for sections MT-P2, P2-P4 and P4-MB and an overall RE of $50 \%$.

Comparing with results obtained in a previously study (Albuquerque et al., 2009a), in the same reactor, but without aeration, the introduction of aeration in the upper part of the reactor (first $8 \mathrm{~cm}$ ) led to an increase in the overall RE of COD, from $18 \%$ to $71 \%$, and ammonia, from $28 \%$ to $50 \%$. Approximately $56 \%$ of COD and $74 \%$ of ammonia were removed in the aerated section MT-P2, which contrasts with the $90 \%$ efficiency observed for both compounds under non-aerated conditions for the same section. The introduction of aeration did not influence the time necessary to attain steady-state conditions since it was observed the same 8 days after the start-up and $8 \mathrm{~h}$ after washing. However, the backwashing cycle was reduced to $5 \mathrm{~h}$ of operation. It took $5 \mathrm{~h}$ to reach an overall head loss of $5 \mathrm{~cm}$ compared to $10 \mathrm{~h}$ when the reactor was not aerated. This difference can be explained by the turbulence caused in section MT-P2 due to the introduction of air, as well as due to the production of large amount of biomass that led to a quick clogging of the bed.

The DO concentrations were stable with average values of $7.6 \pm 0.1 \mathrm{~g} \mathrm{O}_{2} / \mathrm{m}^{3}, 3.3 \pm 0.3 \mathrm{~g} \mathrm{O}_{2} / \mathrm{m}^{3}, 0.5 \pm 0.1 \mathrm{~g} \mathrm{O}_{2} / \mathrm{m}^{3}$ and $0.3 \pm 0.03 \mathrm{~g} \mathrm{O}_{2} / \mathrm{m}^{3}$, respectively, in the influent, $\mathrm{P} 2$, P4 and the effluent. The concentrations of TSS and VSS in P2 and P4 were $60 \pm 5 \mathrm{~g}$ $\mathrm{TSS} / \mathrm{m}^{3}$ and $45 \pm 5 \mathrm{gTSS} / \mathrm{m}^{3}$ and $38 \pm 3 \mathrm{gVSS} / \mathrm{m}^{3}$ and $18 \pm 2 \mathrm{~g}$ $\mathrm{VSS} / \mathrm{m}^{3}$, respectively, which corresponds to a VSS/TSS ratio of 0.63 and 0.40 , respectively, in these two points (i.e., more biomass was produced in the section MT-P2).

After 5 days of operation at steady-state conditions, the head losses in the section MT-P2 increased quickly (from $5 \mathrm{~cm}$ to $9.5 \mathrm{~cm}$ for day 5 and day 6 , respectively) due to clogging of the bed. As a consequence, the removal of COD and ammonia decreased quickly and the steady-state conditions became deteriorated. Therefore, backwashing was scheduled every 5 days during continuous operation, which corresponded to a maximum head loss of $5 \mathrm{~cm}$ allowed for the BAF reactor. $8 \mathrm{~h}$ after the backwashing, the steady-state conditions were observed again, and COD and ammonia removal were fully recovered after another $2 \mathrm{~h}$.

\subsection{Phase II - long term operation}

In Phase II, the ammonia and COD concentrations changed with varying influent conditions. It was found, however, that the steady-state conditions returned in approximately $12 \mathrm{~h}$ after each assay. Regardless of the applied $\mathrm{C} / \mathrm{N}$ ratio, there was no significant removal of $\mathrm{NH}_{4}-\mathrm{N}$ in the assays with lowest influent COD concentrations (from $3.1 \mathrm{~g} \mathrm{COD} / \mathrm{m}^{3}$ to $11.2 \mathrm{~g} \mathrm{COD} / \mathrm{m}^{3}$ ) and lowest influent $\mathrm{NH}_{4}-\mathrm{N}$ concentrations (from $0.3 \mathrm{~g} \mathrm{~N} / \mathrm{m}^{3}$ to $2.1 \mathrm{~g} \mathrm{~N} / \mathrm{m}^{3}$ ), i.e. the assays A6.2.6., A7.2.6., A8.2.6., A8.2.7., A8.2.8. and A9.2.6.). i.e., there is no removal of ammonia for NLR below $15 \mathrm{~g} \mathrm{~N} / \mathrm{m}^{3} \mathrm{~d}$. Xia et al. (2008) observed that the population of nitrifiers was in inverse proportion to $\mathrm{C} / \mathrm{N}$ ratio in carrier biofilm reactors.

The $\mathrm{pH}$ slightly increased throughout the reactor depth reaching higher effluent values in the experiments with higher ammonia removal: 7.2 (influent) to 7.7 (effluent) in assays 8.2.1. and 8.2.2.; $(\mathrm{C} / \mathrm{N}=4) 7.1$ (influent) to 7.8 (effluent) in assays 9.2.1., 9.2.3. and 
$\mathrm{C} / \mathrm{N}: 2$

$\mathrm{pH}, \mathrm{DO}\left(\mathrm{g} \mathrm{O}_{2} / \mathrm{m}^{3}\right)$

$\mathrm{C} / \mathrm{N}: 20 \quad \mathrm{pH}, \mathrm{DO}\left(\mathrm{g} \mathrm{O}_{2} / \mathrm{m}^{3}\right)$
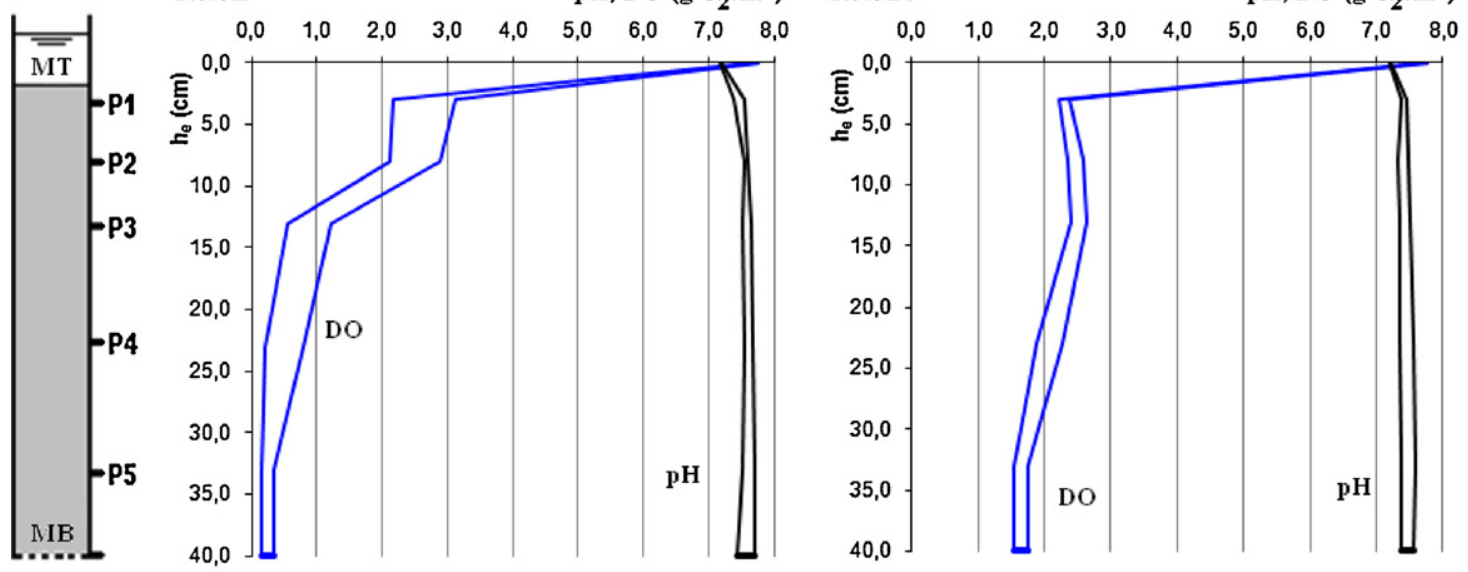

Fig. 4. Typical DO (blue line) and pH (black line) profiles in the experiments of Phase II. (For interpretation of the references to color in this figure legend, the reader is referred to the web version of the article.)

9.2.4. $(\mathrm{C} / \mathrm{N}=2)$. The values of alkalinity also increased in those assays. This finding is in contradiction with ammonia removal via nitrification. The reactor was aerobic in most of its depth (Fig. 4), which favoured ammonia oxidation to nitrite and nitrate (and resulted in alkalinity consumption). However, the removal of acetate (determined as COD) under aerobic conditions was also higher for $\mathrm{C} / \mathrm{N}$ ratios of 2 and 4 and, as reported by Grady et al. (1999), the respective pathway produced alkalinity. Therefore, the production of alkalinity due to acetate oxidation was greater than its consumption by nitrification. The average DO concentrations ranged from $3.1 \mathrm{~g} \mathrm{O}_{2} / \mathrm{m}^{3}$ to $4.1 \mathrm{~g} \mathrm{O}_{2} / \mathrm{m}^{3}$ (P1), $2.1 \mathrm{~g} \mathrm{O}_{2} / \mathrm{m}^{3}$ to $3.8 \mathrm{~g} \mathrm{O}_{2} / \mathrm{m}^{3}$ (P2), $0.5 \mathrm{~g} \mathrm{O}_{2} / \mathrm{m}^{3}$ to $1.1 \mathrm{~g} \mathrm{O}_{2} / \mathrm{m}^{3}$ (P3), $0.4 \mathrm{~g} \mathrm{O}_{2} / \mathrm{m}^{3}$ to $0.8 \mathrm{~g} \mathrm{O}_{2} / \mathrm{m}^{3}$ (P4) and $0.2 \mathrm{~g} \mathrm{O}_{2} / \mathrm{m}^{3}$ to $0.8 \mathrm{~g} \mathrm{O}_{2} / \mathrm{m}^{3}$ (P5), confirming the aerobic conditions in section MT-P2.

Removal rates are normally based on effective reactor volume (Mendoza-Espinosa and Stephenson, 1999; Grady et al., 1999; Stephenson et al., 2003; Chang et al., 2008; Ha et al., 2010). The removal of ammonia started to be significant for NLR above $32.6 \mathrm{~g}$
$\mathrm{N}-\mathrm{NH}_{4} / \mathrm{m}^{3}$.d (assay A6.2.4., $\mathrm{C} / \mathrm{N}=20$ ). The higher removal rates of ammonia $\left(r_{\mathrm{NH}_{4} \mathrm{~N}}\right)$ were observed in the experiments with a low $\mathrm{C} / \mathrm{N}$ ratio (2) and for the higher NLR, as can be observed in Table 2 . These results may be explained by the higher development of nitrifiers for low C/N ratio as observed by Xia et al. (2008). The observed RE in the assays varied in the following ranges: 37.7-44.8\% ( $\mathrm{C} / \mathrm{N}=20), 32.4-53.3 \%(\mathrm{C} / \mathrm{N}=10), 29.6-50.7 \%(\mathrm{C} / \mathrm{N}=4)$ and $57-75 \%(C / N=2)$. The overall removal rates of ammonia (13.6 $\mathrm{g}$ $\mathrm{N}-\mathrm{NH}_{4} / \mathrm{m}^{3} \mathrm{~d}$ to $563.8 \mathrm{~g} \mathrm{~N}-\mathrm{NH}_{4} / \mathrm{m}^{3} \mathrm{~d}$ ) are in agreement with the values (up to $1300 \mathrm{~g} \mathrm{~N}-\mathrm{NH}_{4} / \mathrm{m}^{3} \mathrm{~d}$ ) suggested by Mendoza-Espinosa and Stephenson (1999) for downflow BAF with HRT between $0.4 \mathrm{~h}$ and $1.3 \mathrm{~h}$. A wide range of efficiencies (10-90\%) have been reported for lab-scale RBCs treating ammonium rich wastewater at low $\mathrm{C} / \mathrm{N}$ ratios (Helmer et al., 1999; Pynaert et al., 2002). The RE for COD removal ranged between $26 \%(\mathrm{C} / \mathrm{N}=20)$ and $79 \%(\mathrm{C} / \mathrm{N}=2)$.

Regardless the $\mathrm{C} / \mathrm{N}$ ratio, most of ammonia removal was observed in section MT-P2: $54-74 \%(C / N=20), 53-79 \%(C / N=10)$, $41-76 \%(C / N=4)$ and $49-75 \%(C / N=2)$. For all the assays, between
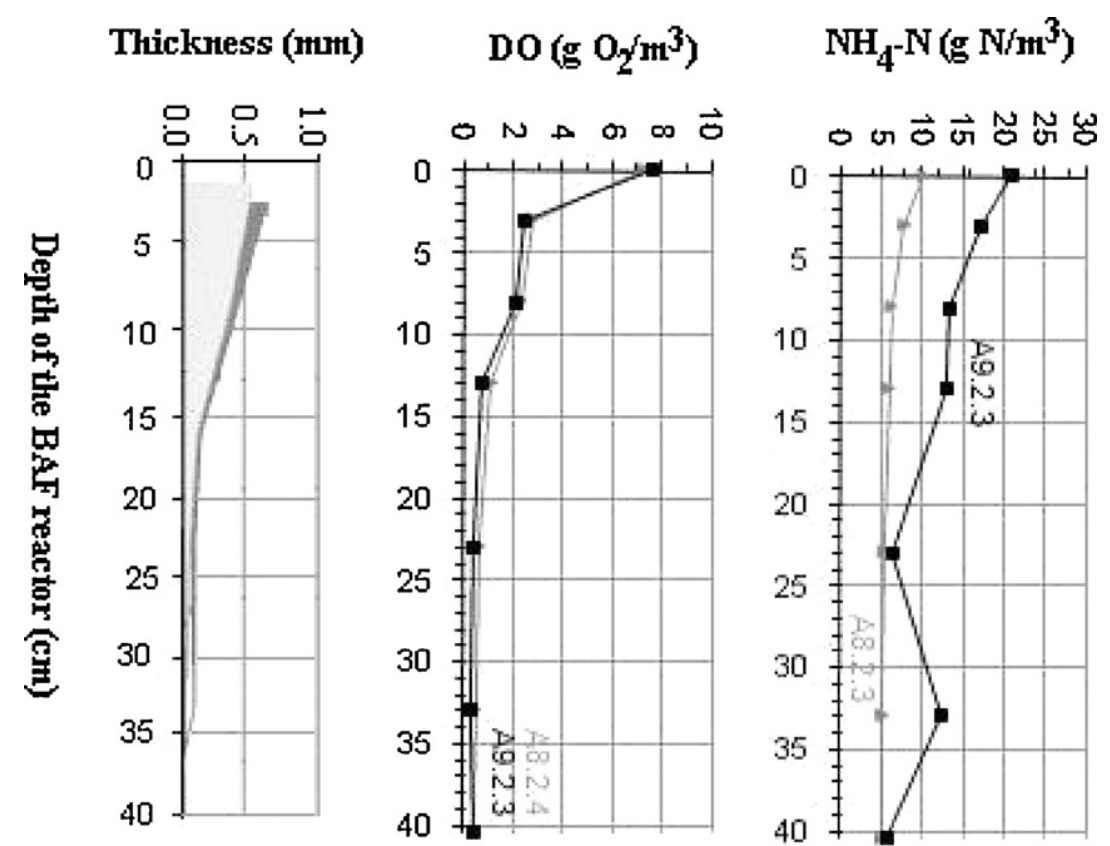

Fig. 5. Vertical profiles of $\mathrm{DO}$ and $\mathrm{NH}_{4}-\mathrm{N}$ concentrations and biofilm thickness for assays A8.2.3. and A9.2.3. 


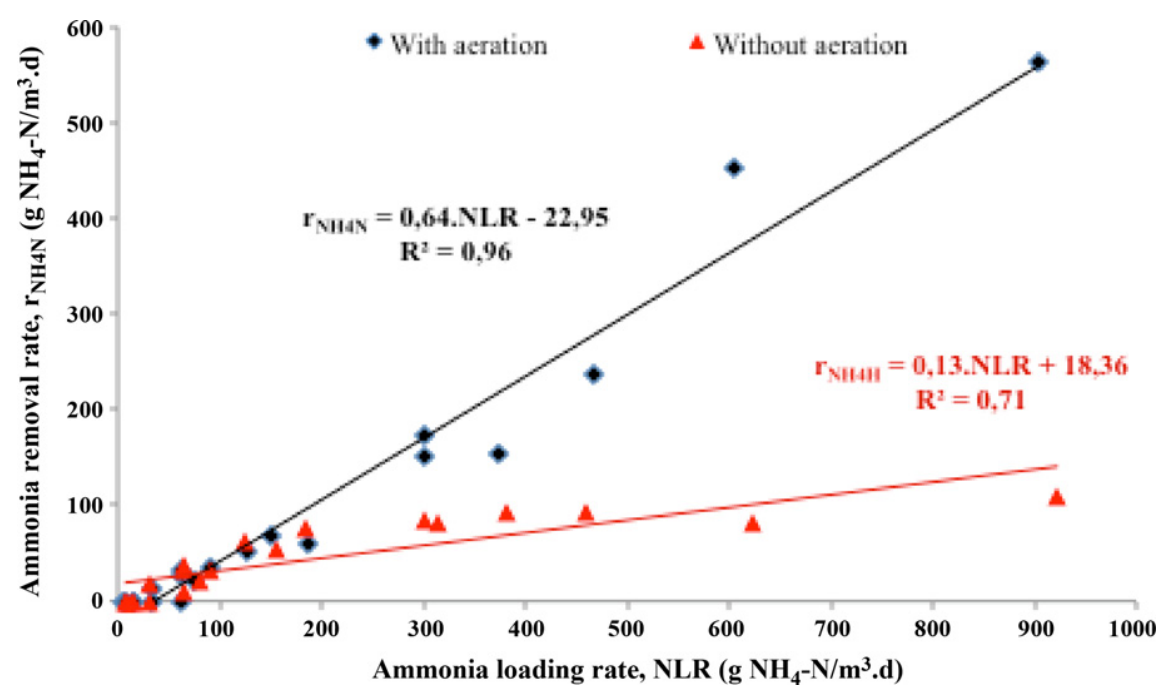

Fig. 6. Correlation between ammonia loading rates and ammonia removal rates for the experiments of Phase II (black line) and for the experiments without aeration (red line, analysed in Albuquerque et al., 2009a). (For interpretation of the references to color in this figure legend, the reader is referred to the web version of the article.)

$82 \%$ and $100 \%$ of ammonia removal occurred in section MT-P4, which can be related to the major availability of DO and the higher biofilm thickness in section MT-P2 (between 0.4 and $0.6 \mathrm{~mm}$ ), as shown in Fig. 5 for one assay at $\mathrm{C} / \mathrm{N}=4$ (A8.2.3.) and another at $\mathrm{C} / \mathrm{N}=2$ (A9.2.3.). The measured average biofilm thickness in P1, $\mathrm{P} 2$ and P4, during steady-state conditions was $0.47 \pm 0.05 \mathrm{~mm}$ (P1), $0.28 \pm 0.05 \mathrm{~mm}$ (P2) and $0.02 \pm 0.01 \mathrm{~mm}$ (P4).

Regression analysis between applied and removed loads of $\mathrm{NH}_{4}-\mathrm{N}$ showed a linear correlation between both variables $\left(R^{2}=0.96, p<0.05\right)$, which was stronger compared to the period when the biofilter was operated without aeration $\left(R^{2}=0.71\right.$, $p<0.05$, Fig. 6). Therefore, regardless of $\mathrm{C} / \mathrm{N}$ ratio, the $\mathrm{NH}_{4}-\mathrm{N}$ loads influenced the respective removal rates for the range of applied loads in this study.

In section MT-P2, where most of the ammonia nitrogen was removed, significant nitrate production was observed. Between $85 \%$ and $100 \%$ of the nitrate generated in the reactor was detected in section MT-P2 and less than 20\% was produced in section P2-P4. Such results were expected since the DO concentrations were higher in section MT-P2 (between $2.1 \mathrm{~g} \mathrm{O}_{2} / \mathrm{m}^{3}$ and $4.1 \mathrm{~g} \mathrm{O}_{2} / \mathrm{m}^{3}$ ) than in the section P2-P4 $\left(0.4 \mathrm{~g} \mathrm{O}_{2} / \mathrm{m}^{3}\right.$ to $\left.1.1 \mathrm{~g} \mathrm{O}_{2} / \mathrm{m}^{3}\right)$. A strong linear relationship $\left(R^{2}=0.84, p<0.05\right)$ was observed between ammonia removal and nitrate production in section MT-P2 (Fig. 7). This condition suggests that practically all the oxidized ammonia in that section was transformed to nitrate by nitrification.

There was no removal of nitrate until sampling point P4, which can be explained by the presence of DO concentrations over $2 \mathrm{~g} \mathrm{O}_{2} / \mathrm{m}^{3}$, but up to $30.7 \%$ of the nitrate (maximum removal rate of $53 \mathrm{~g} \mathrm{~N} / \mathrm{m}^{3} \mathrm{~d}$ ) was removed in the lower section of the reactor (P4-MB), where the $\mathrm{DO}$ ranged between $0.4 \mathrm{~g} \mathrm{O}_{2} / \mathrm{m}^{3}$ and $0.8 \mathrm{~g} \mathrm{O}_{2} / \mathrm{m}^{3}$. That value is lower than the values (up to $5,000 \mathrm{~g}$ $\mathrm{N}-\mathrm{NO}_{3} / \mathrm{m}^{3} \mathrm{~d}$ ) suggested by Mendoza-Espinosa and Stephenson (1999) for a downflow BAF with HRT between $0.4 \mathrm{~h}$ and $1.3 \mathrm{~h}$. However, between $4 \%$ and $18 \%$ of ammonia was also removed in section P4-MB.

These observations suggest that nitrification and denitrification occurred simultaneously in the last section of the reactor. Similar observation was made by Pynaert et al. (2002) in a lab-scale RBC operated under oxygen-limited conditions. According to Grady et al. (1999), denitrification under anoxic environments occurs preferably at DO concentrations under $0.2 \mathrm{~g} \mathrm{O}_{2} / \mathrm{m}^{3}$ (critical value), although in section $\mathrm{P} 4-\mathrm{MB}$ the removal of $\mathrm{N}-\mathrm{NO}_{3}$ was observed in the presence of DO concentrations over that value. These circumstances may suggest both good adaptation capacity of nitrifiers and denitrifiers to low substrate concentrations, and the ability of some species of microorganism to oxidize ammonia and reduce nitrate in the presence of $\mathrm{DO}$ (concentrations between $0.4 \mathrm{~g} \mathrm{O}_{2} / \mathrm{m}^{3}$ and $0.8 \mathrm{~g} \mathrm{O}_{2} / \mathrm{m}^{3}$ ).

Even knowing that submerged BAF may allow a good performance for nitrogen removal, some nitrogen removal pathways still remain poorly understood (Littleton et al., 2003; Garzon-Zuniga et al., 2005). The combined nitrification-denitrification processes have been considered to be the most common method for nitrogen removal from wastewater and it is assumed that each one of these mechanisms is attributed to different functional bacterial groups.

However, Yu et al. (2007) observed the nitrogen loss and DO paradox in full-scale biofilters for drinking water treatment. The observed nitrate production and DO consumption were substantially lower compared to the theoretical stoichiometric amounts required for nitrification and aerobic deammonification was identified as the most probable mechanism that could explain those occurrences. Similar conclusions have been drawn by Albuquerque et al. (2009a) when nitrogen removal and oxygen consumption could not be explained by well-known mechanisms in a nonaerated downflow biofilter. Nitrogen loses were not well explained in another studies using a horizontal subsurface flow constructed wetlands (Albuquerque et al., 2009b; Bialowiec et al., 2012a,b). Ahn (2006) and Paredes et al. (2007) pointed out that alternative nitrate removal pathways such as autotrophic denitrification uses hydrogen, sulphur compounds, ammonia, nitrite and nitrate as energy source and inorganic carbon sources. Such chemolithoautotrophic bacteria as Nitrosomonas are able to nitrify and denitrify in low DO concentrations (Mulder et al., 1995; Schmidt et al., 2003).

In biofilm reactors, low DO concentrations usually lead to a stable, up to $100 \% \mathrm{NO}_{2}-\mathrm{N}$ accumulation (Paredes et al., 2007). Those authors hypothesized that $\mathrm{NO}_{2}-\mathrm{N}$ oxidizers are more exposed to oxygen limiting conditions than $\mathrm{NH}_{4}-\mathrm{N}$ oxidizers, since the former ones are located outside the biofilm, whereas the later are found in the deeper layer of the biofilm. This is in contradiction to a general opinion that faster growing heterotrophs tend to dominate the outer part of a biofilm, while nitrifiers occur along with inerts closer to the substratum (Wanner et al., 2006). Khin and Annachhatre (2004) suggested that under DO limited conditions $(<0.5 \%$ air saturation $)$ a co-culture of aerobic and anaerobic $\mathrm{NH}_{4}-\mathrm{N}$ 


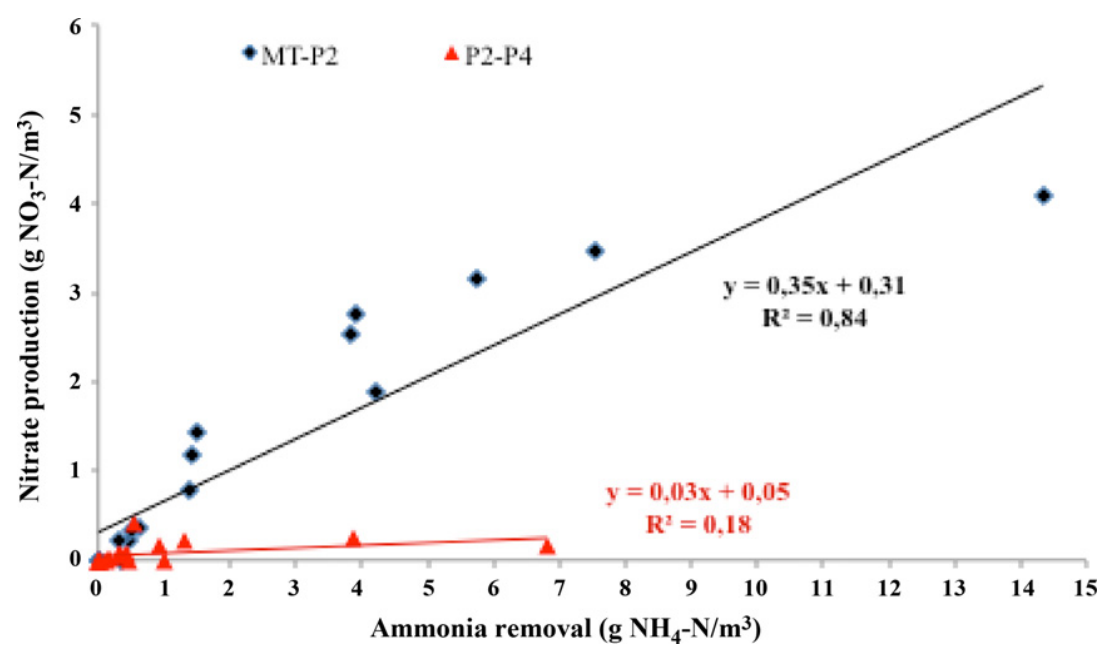

Fig. 7. Correlation between ammonia removal and nitrate production observed in section MT-P2 (black line) and section P2-P4 (red line). (For interpretation of the references to color in this figure legend, the reader is referred to the web version of the article.)

oxidizing bacteria (ANAMMOX) can be established, and this system is responsible for the process termed CANON, OLAND or aerobic deammonification. The interaction of aerobic and anaerobic $\mathrm{NH}_{4}-\mathrm{N}$ oxidizing bacteria under DO limited conditions results in almost complete conversion of $\mathrm{NH}_{4}-\mathrm{N}$ to $\mathrm{N}_{2}$ gas, whereas only small amounts of $\mathrm{NO}_{3}-\mathrm{N}$ are produced.

Therefore, different operation procedures of BAF may be scheduled in order to meet different criteria for the final effluent. The use of aeration in part of the reactor may allow for a superior reduction of organic compounds and ammonia nitrogen, with no guarantee of high reduction of nitrate. This procedure may, however, be useful whenever the concentration of nitrate does not become detrimental to effluent reuse purposes or does not produce significant environmental impacts on receiving environments. The use of intermittent aeration may, therefore, be an interesting option. During the aeration phase, high carbon and ammonia nitrogen removal rates may be achieved. The nitrate produced by nitrification may be eliminated during the non aeration phase as a result of establishing favourable anoxic areas.

\section{Conclusions}

Within the applied ranges of loading rates of ammonia $\left(6 \mathrm{~g} \mathrm{~N} / \mathrm{m}^{3}\right.$.d to $\left.903 \mathrm{~g} \mathrm{~N} / \mathrm{m}^{3} \mathrm{~d}\right)$ and organic compounds $(48 \mathrm{~g}$ $\mathrm{COD} / \mathrm{m}^{3} \mathrm{~d}$ to $2,391 \mathrm{~g} \mathrm{COD} / \mathrm{m}^{3} \mathrm{~d}$ ), the results showed that the partially aerated BAF used in this study allowed carbon removal, nitrification and denitrification simultaneously, at significant removal rates. However, ammonia removal was not observed for NLR below $15 \mathrm{~g} \mathrm{~N}-\mathrm{NH}_{4} / \mathrm{m}^{3}$.d. The long-term operation of the BAF reactor was characterized by stable and relative high removal efficiencies in terms of both $\mathrm{COD}(<80 \%)$ and $\mathrm{NH}_{4}-\mathrm{N}(<75 \%)$. Between $50 \%$ and $70 \%$ of ammonia removal occurred in the upper section of the BAF (MT-P2), where larger biofilm development was observed and DO concentrations remained over $2.1 \mathrm{~g} \mathrm{O}_{2} / \mathrm{m}^{3}$. The applied NLR significantly influenced the removal rates of ammonia for NLR above $32.6 \mathrm{~g} \mathrm{~N}-\mathrm{NH}_{4} / \mathrm{m}^{3} \mathrm{~d}$. At the reactor bottom (P4-MB), simultaneous nitrification and denitrification was observed at DO concentrations between $0.4 \mathrm{~g} \mathrm{O}_{2} / \mathrm{m}^{3}$ and $0.8 \mathrm{~g} \mathrm{O}_{2} / \mathrm{m}^{3}$. The use of submerged BAF partially aerated for the removal of low concentrations of carbon and nitrogen forms appears to be an advantageous polishing solution, which can be used to produce effluents for reuse purposes or to reduce nitrogen loads to be discharged into streams.

\section{References}

Ahn, Y., 2006. Sustainable nitrogen elimination biotechnologies: a review. Process. Biochem. 41, 1709-1721.

A. Albuquerque, 2003. Contribution to the study of residual carbon removal in downflow biological packed beds, Ph.D. Thesis, University of Beira Interior, Covilha, Portugal, pp. 469 (in Portuguese).

Albuquerque, A., Makinia, J., Pagilla, K., 2009a. Investigation of nitrogen removal pathways in a biological packed bed reactor using elementary mass balances. In: Proceedings of the WEF 2nd Specialty Conference on Nutrient Removal 2009: Sustainable Treatment Solutions (CD-ROM), Washington, USA, June 28-July 1, WEF, Alexandria, USA, pp. 117-135.

Albuquerque, A., Oliveira, J., Semitela, S., Amaral, L., 2009b. Influence of bed media characteristics on ammonia and nitrate removal in shallow horizontal subsurface flow constructed wetlands. Biores. Technol. 100, 6269-6277.

APHA-AWWA-WEF, 1999. Standard Methods for the Examination of Water and Wastewater, 20th edition. American Public Health Association, Washington, DC, USA, pp. 1325.

Bialowiec, A., Davies, L., Albuquerque, A., Randerson, P., 2012b. The influence of plants on nitrogen removal from landfill leachate in discontinuous batch shallow constructed wetland with recirculating subsurface horizontal flow. Ecol. Eng. 40, 44-52.

Bialowiec, A., Davies, L., Albuquerque, A., Randerson, P., 2012a. Nitrogen removal from landfill leachate in constructed wetlands with reed and willow: redox potential in the root zone. J. Environ. Manag. 97, 22-27.

Buitrón, G., Quezada, M., Moreno, G., 2004. Aerobic degradation of the azo dye acid red in a sequencing batch biofilter. Biores. Technol. 92 (2), 143-149.

Chang, Y., Henkel, J., Meda, A., Wagner, M., Cornel, P., 2008. Comparison of techniques in greywater treatment. In: Proceedings of the IWA Conference on Sanitation Options in the Asia-Pacific (CD-Rom), Hanoi, Vietnam, November 18-20, IWA, London, UK.

Farabegoli, G., Chiavola, A., Rolle, E., 2009. The biological aerated filter (BAF) as alternative treatment for domestic sewage. Optimization of plant performance. J. Hazard. Mater. 171 (1-3), 1126-1132.

Garzon-Zuniga, M., Lessard, P., Aubry, G., Buelna, G., 2005. Nitrogen elimination mechanisms in an organic media aerated biofilter treating pig manure. Environ. Technol. 26, 361-371.

Grady Jr., C., Daigger, G., Lim, H., 1999. Biological wastewater treatment. In: Revised and Expanded, 2nd edition. Marcel Dekker, New York, USA, pp. 1076.

Ha, J., Ong, S., Surampalli, R., 2010. Impact of media type and various operating parameters on nitrification in polishing biological aerated filters. Environ. Eng. Res. 15 (2), 79-84.

He, S., Xue, G., Kong, H., 2007. The performance of BAF using natural zeolite as filter media under conditions of low temperature and ammonium shock load. J. Hazard. Mater. 143, 291-295.

Helmer, C., Kunst, S., Juretschko, S., Schmid, M.C., Schleifer, K.H., Wagner, M., 1999. Nitrogen loss in a nitrifying biofilm system. Water Sci. Technol. 39 (7), 13-21.

Hidaka, T., Tsuno, H., 2004. Development of a biological filtration model applied for advanced treatment of sewage. Water Res. 38, 335-346.

Jenssen, P., Krogstad, T., Paruch, A., Mæhlum, T., Adam, K., Arias, C., Heistad, A. Jonsson, L., Hellström, D., Brix, H., Yli-Halla, M., Vråle, L., Valv, M., 2010. Filter bed systems treating domestic wastewater in the Nordic countries - performance and reuse of filter media. Ecol. Eng. 36 (12), 1651-1659. 
Jeong, J., Hidaka, T., Tsuno, H., Oda, T., 2006. Development of biological filter as tertiary treatment for effective nitrogen removal: biological filter for tertiary treatment. Water Res. 40, 1127-1136.

Khin, T., Annachhatre, A., 2004. Novel microbial nitrogen removal processes. Biotech. Adv. 22, 519-532.

Lei, G., Qi, B., Wang, Z., Wang, J., 2009. Treatment of municipal sewage by biological aerated filter (BAF) using burned clay pellet as media. Int. J. Environ. Pollut. 37 (2-3), 186-204.

Littleton, H., Daigger, G., Strom, P., Cowan, R., 2003. Simultaneous biological nutrient removal: evaluation of autotrophic denitrification, heterotrophic nitrification, and biological phosphorus removal in full-scale systems. Water Environ. Res. $75,138-150$.

Liu, Y., Yang, T., Yuan, D., Wu, X., 2010. Study of municipal wastewater treatment with oyster shell as biological aerated filter medium. Desalination 254 , 149-153.

Mendoza-Espinosa, L., Stephenson, T., 1999. A review of biological aerated filters for wastewater treatment. Environ. Eng. Sci. 16, 201-216.

Mulder, A., van de Graaf, A., Robertson, L., Kuenen, J., 1995. Anaerobic ammonium oxidation discovered in a denitrifying fluidized bed reactor. FEM Microb. Ecol. 16 (3), 177-184.

Paredes, D., Kuschk, P., Mbwette, T., Stange, F., Müller, R., Köser, H., 2007. New aspects of microbial nitrogen transformations in the context of wastewater treatment - a review. Eng. Life Sci. 7 (1), 13-25.

Pynaert, K., Sprengers, R., Laenen, J., Verstraete, W., 2002. Oxygen-limited nitrification and denitrification in a lab-scale rotating biological contactor. Environ. Technol. 23, 353-362.
Schmidt, I., Sliekers, O., Schmid, M., Bock, E., Fuerst, J., Kuenen, J., Jetten, M., Strous, M. 2003. New concepts of microbial treatment processes for the nitrogen removal in wastewater. FEMS Microb. Rev. 27, 481-492.

Schulz, J., Menningmann, G., 2008. Submerged fixed-bed reactors. In: Rehm, H., Reed, G. (Eds.), Biotechnology: Environmental Processes I, vol. 11a., 2nd edition. Wiley $\mathrm{VCH}$, Weinheim, Germany.

Stephenson, T., Pollard, S., Cartmell, E., 2003. Feasibility of biological aerated filters (BAF) for leachate treatment. In: Proc. 9th International Waste Management and Landfill Symposium (CD-Rom), S. Margherita di Pula, Cagliari, Italy, Oct. 6-10, CISA, Italy, pp. 10.

Tchobanoglous, G., Burton, F.L., Stensel, H.D., 2003. Wastewater Engineering. Treatment and Reuse, 4th Edition. McGraw-Hill, New York, USA.

Villaverde, S., Fdz-Polanco, F., Garcia, 2000. Nitrifying biofilm acclimation to free ammonia in submerged biofilters: startup influence. Water Res. 34(2), 602-610.

Wanner, O., Eberl, $\mathrm{H}$, Morgenroth, E, Noguera, D., Picioreanu, C, Rittmann, B, van Loosdrecht, M., 2006. Mathematical Modeling of Biofilms, Scientific and Technical Report No. 18. IWA Publishing, London, UK.

Yang, J., Liu, W., Li, B., Yuan, H., Tong, M., Gao, J., 2010. Application of a novel backwashing process in upflow biological aerated filter. J. Environ. Sci. 22 (3), 362-366.

Yu, X., Qi, Z., Zhang, X., Yu, P., Liu, B., Zhang, L., Fu, L., 2007. Nitrogen loss and oxygen paradox in full-scale biofiltration for drinking water treatment. Water Res. 41 , $1455-1464$.

Xia, S., Li, J., Wang, R., 2008. Nitrogen removal performance and microbial community structure dynamics response to carbon nitrogen ratio in a compact suspended carrier biofilm reactor. Ecol. Eng. 32 (3), 256-262. 